\section{Side effects of nalbu- phine while reversing opioid-induced respiratory depression: report of four cases}

Nalbuphine hydrochloride, an agonist-antagonist opioid, is reported to reverse the respiratory depression of moderate doses of fentanyl $\left(20 \mu \mathrm{g} \cdot \mathrm{kg}^{-1}\right)$ and still provide good analgesia. We report four patients having abdominal aortic aneurysm repair in which we attempted to reverse the respiratory depression of large doses of fentanyl $\left(50-75 \mu \mathrm{g} \cdot \mathrm{kg}^{-1}\right)$ with nalbuphine (0.3 $\mathrm{mg} \cdot \mathrm{kg}^{-1}, 0.1 \mathrm{mg} \cdot \mathrm{kg}^{-1}$ or $\left.0.05 \mathrm{mg} \cdot \mathrm{kg}^{-1}\right)$. Nalbuphine reversed respiratory depression in all four patients and the respiratory rate increased from 10 to 23 breaths per minute. end-tidal $\mathrm{CO}_{2}$ decreased from $7.0 \pm 0.3$ per cent to $5.6 \pm 0.7$ per cent, and peak inspiratory pressure after 0.1 seconds increased from $4 \pm 1.4$ to $13 \pm 2.6 \mathrm{mmHg}$. However, hypertension, increased heart rate, and significant increase in analogue pain scores accompanied reversal of respiratory depression. Agitation, nausea, vomiting, and cardiac dysthythmias also were observed frequently. We do not recommend the use of nalbuphine to facilitate early extubation of the trachea after large doses of fentanyl for abdominal aortic surgery.

On dit que l'hydrochlorure de nalbuphine, un morphinique agoniste-antagoniste, peut contrecarrer la dépression re. spiratoire induite par des doses moyennes de fentanyl $(20$ $\mu \mathrm{g} \cdot \mathrm{kg}^{-l}$ ) tout en préservant l'analgésie. Nous avons injecté de. la nalbuphine $\left(0,3,0,1\right.$ ou $\left.0,05 \mathrm{mg} \cdot \mathrm{kg}^{-1}\right)$ dans quatre cas de résection d' anévrysme de l'aorte abdominale où on avait utilisé de bonnes doses de fentanyl (50-75 $\left.\mu \mathrm{g} \cdot \mathrm{kg}^{-1}\right)$. La dépression respiratoire est disparue dans chaque cas, la fréquence respira-

\section{Key words}

ANALGESICS: fentanyl, nalbuphine; ANTAGONISTS, NARCOTIC: nalbuphine.

From the Department of Anaesthesia, Notre Dame Hospital, University of Montreal, * Quebec, Canada H2L 4M1 and Department of Anesthesiology, Mayo Clinic, $¥$ Rochester, Minnesota, U.S.A. 55905.

Address correspondence to: Dr. M. Nugent, Department of Anesthesiology, Medical College of Ohio, P.O. Box 10008, Toledo, Ohio 43699-0008, U.S.A.
Gilbert A. Blaise MD,* Michael Nugent MD, $\dagger$

John C. McMichan MBBS PhD,$\ddagger$

Philippe A.C. Durant MD PhD $\ddagger$ toire passant de 10 à 2.3 respiration/minute, le $\mathrm{CO}_{2}$ en fin d'expiration de 7,0 $\pm 0,3$ à 5,6 \pm 0.7 pour cent et la pression inspiratoire maximale à 0,1 seconde augmentant de $4 \pm 1,4 d$ $13 \pm 2,6 \mathrm{mmHg}$. Toutefois, cela s'est accompagné d'hypertension et d'une augmentation du pouls et de la doulcur à l'échelle analogique et souvent, d'agitation, de nausées, de vomissements et d'arythmies cardiaques. Dans les cas de chirurgie de l'aorte abdominale où on a utilisé du fentanyl d̀ dose élevée, il n'est pas approprié d'employer la nalbuphine pour favoriser une extubation précoce de la trachée.

Anaesthesia with a large dose of opioids is often used for patients undergoing cardiac and vascular surgery. It provides haemodynamic stability and excellent postoperative analgesia. The associated respiratory depression may require the use of postoperative mechanical ventilation for as long as 24 to $48 \mathrm{hr}$ in the intensive care unit. Respiratory depression can be reversed by naloxone, a pure opiate antagonist which reverses not only the respiratory depression but also the analgesia. In such cases, naloxone adminstration may also be followed by hypertension, cardiac dysrhythmias,' and pulmonary oedema. $^{2}$ Its short duration of action does not prevent secondary respiratory depression. It has been shown that nalbuphine hydrochloride, an agonist-antagonist, can reverse the respiratory depression of moderate-dose fentanyl and still provide good analgesia. ${ }^{3-5} \mathrm{We}$ were interested in determining: (1) Does nalbuphine safely reverse the respiratory depression after high-dose fentanyl anaesthesia for abdominal vascular surgical procedures? (2) Does nalbuphine reverse the analgesic effect of fentanyl? (3) Does nalbuphine act for long enough to avoid secondary respiratory depression? (4) What are the secondary effects of reversing fentanyl analgesia with nalbuphine?

\section{Report of four cases}

The protocol was approved by the Mayo Institutional Review Board. The four patients had identical anaesthet- 
ic management which included their usual cardiovascular medications (antihypertensive and beta blockers) before surgery but no premedication with sedatives or opioids. Induction of anaesthesia was with thiopentone, 75-100 $\mathrm{mg}$, and fentanyl, $50-75 \mu \mathrm{g} \cdot \mathrm{kg}^{-1}$, and muscle relaxation was provided with pancuronium. Anaesthesia was maintained with $\mathrm{N}_{2} \mathrm{O} / \mathrm{O}_{2}$ (50/50 per cent) and isoflurane. A flow-directed pulmonary artery catheter was inserted in each patient. At the end of the surgical procedure, the residual effects of the muscle relaxants were reversed with neostigmine and atropine. The trachea of each patient remained intubated and the lungs were ventilated mechanically in the intensive care unit. The respiratory and cardiac status of each patient was then assessed and nalbuphine was administered when they were stable. Stability was defined as: (1) cardiac index $>2.5 \mathrm{~L} \cdot \mathrm{min}^{-1}$; (2) blood pressure, heart rate and cardiac rhythm stable, and haemodynamic variables within 15 per cent of preoperative values; (3) infusion rate of dopamine $<4 \mu \mathrm{g}$. $\mathrm{kg}^{-1} \cdot \mathrm{min}^{-1}$ and of sodium nitroprusside $<2 \mu \mathrm{g} \cdot \mathrm{kg}^{-1}$. $\min ^{-1}$; (4) urine output $>1 \mathrm{ml} \cdot \mathrm{kg}^{-1} \cdot \mathrm{hr}^{-1}$; and (5) $\mathrm{PO}_{2}$ greater than $70 \mathrm{mmHg}$ with an $\mathrm{FIO}_{2} \leq 0.5$ and a positive end expiratory pressure $\leq 5 \mathrm{~cm} \mathrm{H}_{2} \mathrm{O}$.

The level of analgesia was assessed using an analogue scale. Mechanical ventilation was changed from an assist-control to an IMV mode with a rate of two breaths $\cdot \min ^{-1}$. Total respiratory rate was counted and a peak inspiratory pressure after $0.1 \mathrm{sec}$ was measured. ${ }^{6}$ Ventilator settings were returned to a control mode if the end-tidal $\mathrm{CO}_{2}$ reached $50 \mathrm{mmHg}$ or if the patients developed hypertension, tachycardia $(>20$ per cent increase) or cardiac dysrhythmias. After IV nalbuphine patients were allowed to breathe spontaneously. The haemodynamic and respiratory measurements were then repeated.

Before the administration of nalbuphine the four patients were asleep but arousable. The analogue pain score was less than 1.5 for each patient. None was able to tolerate the IMV mode of ventilation because of $\mathrm{CO}_{2}$ elevation or haemodynamic response.

Nalbuphine was given in one of three doses $(0.3 \mathrm{mg}$. $\mathrm{kg}^{-1}, 0.1 \mathrm{mg} \cdot \mathrm{kg}^{-1}$ (two patients) and $0.05 \mathrm{mg} \cdot \mathrm{kg}^{-1}$ ). After nalbuphine all patients demonstrated increases in arterial blood pressure, respiratory rate and pain scores. The end-tidal $\mathrm{CO}_{2}$ also decreased (Table). Agitation, nausea, vomiting, and cardiac dysrhythmias were observed frequently.

The first patient, nalbuphine $0.3 \mathrm{mg}^{-1}$, complained of severe pain after nalbuphine. He received morphine and his trachea remained intubated on the CPAP mode of ventilation for an additional $18 \mathrm{hr}$. Patients 2 and 3, nalbuphine $0.1 \mathrm{mg} \cdot \mathrm{kg}^{-1}$, were agitated, nauseated, and vomiting. They were sedated with diazepam and morphine and ventilated mechanically for the first postoperative day. Patient number 4 , nalbuphine $\left(0.05 \mathrm{mg} \cdot \mathrm{kg}^{-1}\right.$, became very agitated and extubated himself. This patient became acutely psychotic and required major tranquillizers and continuing supportive care by physicians and nursing staff. The study was discontinued after four patients had received nalbuphine, because of severe side effects (Table).

\section{Discussion}

Nalbuphine, even at low doses, reverses the respiratory depression of high-dose fentanyl. Before the injection of nalbuphine, none of these four patients could sustain spontaneous ventilation, and all had an end-tidal $\mathrm{PCO}_{2}$ $>50 \mathrm{mmHg}$. After nalbuphine all patients increased their respiratory rate and minute ventilation and the two patients who were allowed to breathe spontaneously (nalbuphine, $0.3 \mathrm{mg} \cdot \mathrm{kg}^{-1}$ and $0.05 \mathrm{mg} \cdot \mathrm{kg}^{-1}$ ) had no recurrent respiratory depression. Because nalbuphine induced side effects, its dose was progressively reduced. The first patient received $0.3 \mathrm{mg} \cdot \mathrm{kg}^{-1}$; the next two received $0.1 \mathrm{mg} \cdot \mathrm{kg}^{-1}$ and the last received $0.05 \mathrm{mg} \cdot \mathrm{kg}^{-1}$ nalbuphine. Jaffe et al. in a study done contemporaneously with this study, examined the effects of nalbuphine antagonism of fentanyl-induced ventilatory depression in patients after coronary artery bypass surgery. ${ }^{7}$ Their protocol included the administration of incremental doses of nalbuphine from 0.03 to $0.3 \mathrm{mg} \cdot \mathrm{kg}^{-1}$. Their median dose prior to extubation was $0.06 \mathrm{mg} \cdot \mathrm{kg}^{-1}$. One of their

TABLE Effect of nalbuphine on pain scale and on respiratory and haemodymic variables

\begin{tabular}{lccl}
\hline & \multicolumn{2}{l}{ Nalbuphine $(n=4)$} & \\
\cline { 2 - 3 } & Before & After & $\begin{array}{l}P \\
\text { (paired-test) }\end{array}$ \\
\hline Respiratory ratc (permin) & $10.0 \pm 1.0$ & $23.0 \pm 2.0$ & $<0.001$ \\
ETCO $(\%)$ & $7.0 \pm 0.3$ & $5.6 \pm 0.7$ & $<0.010$ \\
$P$ 0.1 S $(\mathrm{mmHg})$ & $4.0 \pm 1.4$ & $3.0 \pm 2.6$ & $<0.001$ \\
Heart rate & $70.0 \pm 10.0$ & $84.0 \pm 2.0$ & $<0.05$ \\
Systolic blood pressure & $139.0 \pm 29.0$ & $177.0 \pm 24.0$ & $<0.001$ \\
Diastolic blood pressure & $81.0 \pm 14.0$ & $94.0 \pm 14.0$ & $<0.001$ \\
Pain scale & $0.8 \pm 0.2$ & $4.6 \pm 0.3$ & $<0.05$ \\
\hline
\end{tabular}


patients renarcotized four hours after extubation and required an additional dose of nalbuphine. ${ }^{3}$ Nine of the treated patients required vasoactive agents or beta blockers for hypertension or tachycardia associated with the administration of nalbuphine, and eight of 18 patients were not satisfied with nalbuphine analgesia and required morphine for pain relief. ${ }^{7}$ Jaffe et al. concluded that nalbuphine was an effective opiate antagonist after fentanyl anaesthesia, but its use was associated with side effects and the analgesia for post-sternotomy patients may be unsatisfactory unless the dose is carefully titrated to the minimum required to antagonize respiratory depression. ${ }^{7}$ After abdominal aortic aneurysm repair, patients generally have greater requirements for opioid analgesics than after coronary artery bypass surgery. This may make the titration of an agonist-antagonist agent such as nalbuphine even more difficult in these patients than in those after coronary artery bypass.

Nalbuphine significantly reduced the level of analgesia as assessed by the analogue pain score. Treated patients required morphine injections for pain. Patients also had serious secondary effects such as hypertension, tachycardia, cardiac dysrhythmias, agitation, nausea, and vomiting. Our patients were pain-free before nalbuphine injection and had pain after nalbuphine. This reversal of analgesia with nalbuphine confirms the data of others ${ }^{7.8}$ who have used nalbuphine to reverse fentanyl-induced respiratory depression after coronary artery bypass. In contrast to our patients using high-dose fentanyl, Latash et al. ${ }^{3}$ found that nalbuphine did not reverse or may even improve the analgesia in postoperative patients anaesthetized with low-dose fentanyl. Analgesia and sedation were improved by nalbuphine after reversal of epidural morphine-induced respiratory depression. ${ }^{9}$ Our report cannot explain why nalbuphine reversed the respiratory depression and improved analgesia in patients who received moderate-dose fentanyl $\left(20 \mu \mathrm{g} \cdot \mathrm{kg}^{-1}\right),{ }^{3}$ whereas it reversed the analgesic effect in patients anaesthetized with high-dose fentanyl. ${ }^{8,10}$

Reversal with naloxone of a single large dose of opiate in rats resulted in severe side effects (hypertension, tachycardia, agitation, and diarrhoea) (Yaksh TL, University of California, San Diego, personal communication) while reversal after a single small dose of narcotic rarely caused side effects. These findings are analogous to ours; severe side effects are seen after reversal high-dose of fentanyl while reversal of moderate doses of fentanyl has not been reported to reverse analgesia or result in clinically important problems. Whether our findings of a reduction in analgesia and reduction of severe side effects after high-dose fentanyl a few hours after its administration represent an acute clinical withdrawal syndrome is controversial.
Some authors have claimed that patients do not tolerate tracheal intubation after narcotic antagonism with nalbuphine and that agitation is due to laryngeal stimulation. " Nalbuphine could have an antagonistic effect on morphine receptors of the solitary nucleus and the nuclei of the ninth and tenth cranial nerves and reverse the fentanyl depression on these receptors. The tracheas of three of the four treated patients were kept intubated for $24 \mathrm{hr}$ after nalbuphine injection, and these patients required additional morphine and diazepam administration. We do not know if extubation would have reduced the agitation of these patients. The fourth patient who extubated his trachea was the most agitated. All patients complained of abdominal pain.

Nalbuphine is considered to be a mu-receptor antagonist, and a kappa, and weak sigma agonist. ${ }^{12}$ Whether nalbuphine acts as a kappa agonist or a mu antagonist may depend on the ratio of nalbuphine to fentanyl. The stimulation of sigma receptors is thought to be responsible for the agitation. One of four patients became psychotic after nalbuphine and he needed psychiatric support for several days. We do not know if nalbuphine was responsible for this, but the psychosis did occur after the nalbuphine injection.

Because of the possibility of renarcotization with the small doses of nalbuphine reported by Jaffe et al. in coronary artery bypass patients, ${ }^{7}$ and because of the side effects reported in our study, we do not recommend the use of nalbuphine to facilitate early extubation of the trachea after large-dose fentanyl for abdominal aortic aneurysm surgery. Compared with naloxone, nalbuphine may have the theoretical advantage of a prolonged duration of action, but we found that, as with naloxone, nalbuphine resulted in a significant reduction of postoperative analgesia and had severe side effects.

\section{References}

1 Azar I, Turndorf $H$. Severe hypertension and multiple atrial premature contractions following naloxone administration. Anesth Analg 1979; 58: 524-5.

2 Flacke JW. Flacke WE, Williams GS. Acute pulmonary edema following naloxone reversal of high-dose morphine anesthesia. Anesthesiology 1977; 47: 376-8.

3 Latash L, Probst S, Dudziak R. Reversal by nalbuphine of respiratory depression caused by fentanyl. Anesth Analg 1984; 63: 814-6.

4 Zsigmond EK, Durrani Z, Barabas E, Wang XY, Tran L. Endocrine and hemodynamic effects of antagonism of fentanyl-induced respiratory depression by nalbuphine. Anesth Analg 1987; 66: 421-6.

5 Whitelaw WA, Dereene JP, Milic-Emili J. Occlusion pressure as a measure of respiratory center output in conscious man. Respir Physiol 1975; 23: 181-9. 
6 Jaffe RS, Moldenhauer CC, Hug CC Jr et al. Nalbuphine antagonism of fentanyl-induced ventilatory depression: a randomized trial. Anesthesiology 1988; 68: 254-60.

7 Ramsay JG, Higgs BD, Wynands JE, Robbins $R$, Townsend $G E$. Early extubation after high-dose fentanyl anacsthesia for aortocoronary bypass surgery: reversal of respiratory depression with low-dose nalbuphine. Can anacsth Soc J 1985; 32: 597-606.

8 Penning $J P$, Samson B, Baxter $A$. Nalbuphine reverses epidural morphine-induced respiratory depression. Anesth Analg 1986; 65: S1 19.

9 Moldenhauer CC, Roach GW. Finlayson DC et al. Nalbuphine antagonism of ventilatory depression following high-dose fentanyl anaesthesia. Anesthesiology 1985; 62: $647-50$.

10 Samson B, Baxter A, Penning J. Does nalbuphine reverse opioid obtuned laryngeal reflexcs? (Letter) Can Anaesth Soc J 1986; 33: 825.

11 Schmidt WK, Tam SW, Shotzberger GS, Smith DH Jr, Clark $R$, Vernier TG. Nalbuphinc. Drug Alcohol Depend 1985; 14: 339-62. 